\title{
U-PB DATING OF DEFORMED MAFIC DYKE AND HOST GNEISS: IMPLICATIONS FOR UNDERSTANDING REWORKING PROCESSES ON THE WESTERN MARGIN OF THE ARCHAEAN UAUÁ BLOCK, NE SÃO FRANCISCO CRATON, BRAZIL
}

\author{
ELSON PAIVA OLIVEIRA ${ }^{1}$, ZORANO SÉRGIO SOUZA ${ }^{2}$ AND LUIZ CESAR CORRÊA GOMES
}

\begin{abstract}
U-Pb ages of deformed mafic dyke and host migmatitic grey gneiss from the transition zone between the Archaean Uauá Block and the Caldeirão Belt are presented. Titanites from the metamorphic dyke's margin and zircons from the gneiss were dated at $2,039 \pm 2$ Ma and 2,956 $\pm 39 \mathrm{Ma}$, respectively. The Sm-Nd data $\left(\mathrm{T}_{\mathrm{PM}}=2,965 \mathrm{Ma}\right.$ and $\left.\varepsilon_{\mathrm{Nd}(\mathrm{t})}=1.69\right)$ on the gneiss, coupled with the U-Pb data on both dyke and gneiss, suggest that an Archaean granodioritic batholith, probably originated at an Andean-type continental margin, was intruded by mafic dykes, and subsequently was reworked during the Palaeoproterozoic collisional event associated with the development of the Salvador-Curaçá Orogen.
\end{abstract}

Keywords: U-Pb geochronology, deformation, crustal evolution

INTRODUCTION Reworking of older Archaean terrains by younger orogenic events is a common feature of Precambrian areas within several continents. Reworking processes include folding and (or) disruption of older structures, metamorphism, crustal melting, mobility of chemical elements and opening of isotope systems, sometimes also intrusion of new mantle-derived magmas. Dating reworking events has been possible by means of good field relations and the availability of syndeformational minerals suitable for isotope analysis.

On the western margin of the Archaean Uauá Block, northeastern São Francisco Craton, migmatic grey gneisses are intruded by mafic dykes. Both rock units were subsequently reworked during a collisional event associated with the development of the Palaeoproterozoic Salvador-Curaçá Orogen. As a result, the grey gneisses are refolded, and intruded by pegmatites along the new foliation plane, and the mafic dykes are boudinaged and disrupted under amphibolite facies condition. Conventional $\mathrm{U}-\mathrm{Pb}$ dating of zircons from one host gneiss and syndeformational titanite from the margin of one dyke, along with whole-rock Sm-Nd data, indicate that the dyke was deformed at ca. 2,039 Ma and the gneiss (2,956 Ma) underwent little isotope disturbance. The regional implications of this study are also discussed.

GEOLOGIC SETTING Mafic dykes are a major geological component of the Uauá Block (Fig. 1), one of the several Archaean remnants exposed in the São Francisco Craton, eastern Brazil. On the basis of cross-cutting relations, two main dyke swarms (N-NE- and $\mathrm{NW}$-trending groups) can be recognized. The younger one, i.e. the $\mathrm{N}$ NE-trending group, was not affected by ductile deformation and is bimodal in composition (tholeiite and norite), whereas the other one comprises strongly deformed and metamorphosed basic dykes, now transformed into amphibolite. These dyke swarms intrude Archaean basement rocks (layered mafic-ultramafic complexes, banded gneisses, tonalitic to granodioritic orthogneisses), but are unconformably overlain by the Palaeoproterozoic Rio Capim Volcano-PlutonicSedimentary Sequence, for which Oliveira et al. (1998) constrained ages in the time span 2,222 Ma to 2,096 Ma.

Precise dating of the mafic dykes has been hampered by paucity of suitable minerals, such as zircon and baddeleyite. Nevertheless, wholerock and mineral $\mathrm{Rb} / \mathrm{Sr}$ isochrons presented by Bastos Leal et al (1994) indicate two age groups for the N-NE-trending tholeiite dyke swarm, viz. $2.38 \mathrm{Ga}$ and $1.98 \mathrm{Ga}$.

The Uauá Block (Fig. 1) is bounded to the east by flat-laying Neoproterozoic metasediments of the Sergipano Orogen, or younger units, and to the west by a sequence of steeply dipping quartzites, metapelites, migmatitic gneisses, deformed granitoids and mafic rocks, collectively called Caldeirão Belt (Jordan 1972). Although less abundant, mafic dykes of the Uauá Block have also been observed in the Caldeirão Belt where they have undergone deformation and metamorphism under amphibolite facies conditions. A prominent, at least two-kilometer-wide, steeply dipping ductile deformation zone, with associated narrow shear zones, separates the Caldeirão Belt from rocks of the Uauá Block.
Although mafic dykes of the N-NE group of the Uauá Block are generally not deformed, they do are as the above referred to shear zone is approached. Thus, from east to west, they gradually change from undeformed, weakly- to non-metamorphic tholeiite to along-strike boudinaged metatholeiite and amphibolite. Intrusive field relations between dykes and country rock gneisses that are easily recognized outside the deformation zone become more difficult to be observed within it. Yet, the host gneisses are refolded and may locally display coaxial or non-coaxial fold interference patterns.

Sampling Site On outcrop UA96-2 (446812E, 8904890N - Fig. 1 ), at the unpaved road Uauá-Monte Santo, one mafic dyke is structurally conformable with the host migmatitic grey gneiss, both presenting a tectonic planar fabric $\left(S_{1}\right.$ on dyke and $S_{2}$ on gneiss) oriented $\mathrm{N} 56^{\circ} \mathrm{W} / 82^{\circ} \mathrm{NE}$. In spite of the strong deformation, intrusive contacts between dyke and gneiss can be inferred because of abrupt contact, folding of a previous metamorphic banding on the gneiss, local truncation of the gneissic fabric, and a fine grained texture of the dyke margin (older cooling margin). Several ductile shear zones affect the mafic dyke, the gneiss and syntectonic granitic pegmatites. They often show dextral kynematics, but sinistral E-W extensional C'bands are also common. The mafic dyke itself is boudinaged and disrupted, with measured stretching of at least $41 \%$.

The deformed tholeiite dyke of outcrop UA96-2 has primary subophitic texture in dyke's center but is strongly foliated and recrystallized under amphibolite facies conditions at the margins. As deformation progressed the original igneous mineralogy (pyroxenes, plagioclase, pyrite, ilmenite and magnetite) was converted into a metamorphic assemblage composed of plagioclase, hornblende, titanite and a few relicts of ilmenite and Ca-pyroxene. Titanite occurs as stringlets between elongated amphibole grains and around stretched ilmenite. These textural features strongly support a syndeformational (metamorphic) origin for the titanite rather than magmatic.

The host migmatitic grey gneiss has a granodioritic composition and is dominantly composed of biotite, quartz and plagioclase, and minor K-feldspar, muscovite, zircon and calcite.

Analytical Procedures Analytical data were obtained at the Isotope Geochemistry Laboratory of the University of Kansas, USA. Abraded and non-abraded fractions of zircon single grains and titanite multigrains were spiked with a mixed ${ }^{205} \mathrm{~Pb}^{235} \mathrm{U}$ tracer solution and dissolved in $\mathrm{HF}$ and $\mathrm{HCl}$ in microcapsules, using procedures modified after Krogh (1973). $\mathrm{U}$ and $\mathrm{Pb}$ of titanite and zircon were purified using $\mathrm{HCl}-\mathrm{HBr}$ chemistry modified after Tilton (1973) and $\mathrm{HCl}$ chemistry after Krogh (1973), respectively. Pb and U samples were loaded together onto single rhenium filaments with phosphoric acid and silica gel, for isotopic analysis on a VG Sector multi-collector mass spectrometer equipped with a Daly detector. Mass discrimination correction of 0.1 to $0.15 \%$ per mass unit was determined periodically by analysis of NBS SRM 982, equal-atom Pb. During these analysis, analytical blanks varied from 5 to $25 \mathrm{pg}$ for Pb. PBDAT (Ludwig 1980) and ISOPLOT (Ludwig 1990) were used to reduce raw mass spectrometer data; correct for blanks; and calculate uncertainties, 

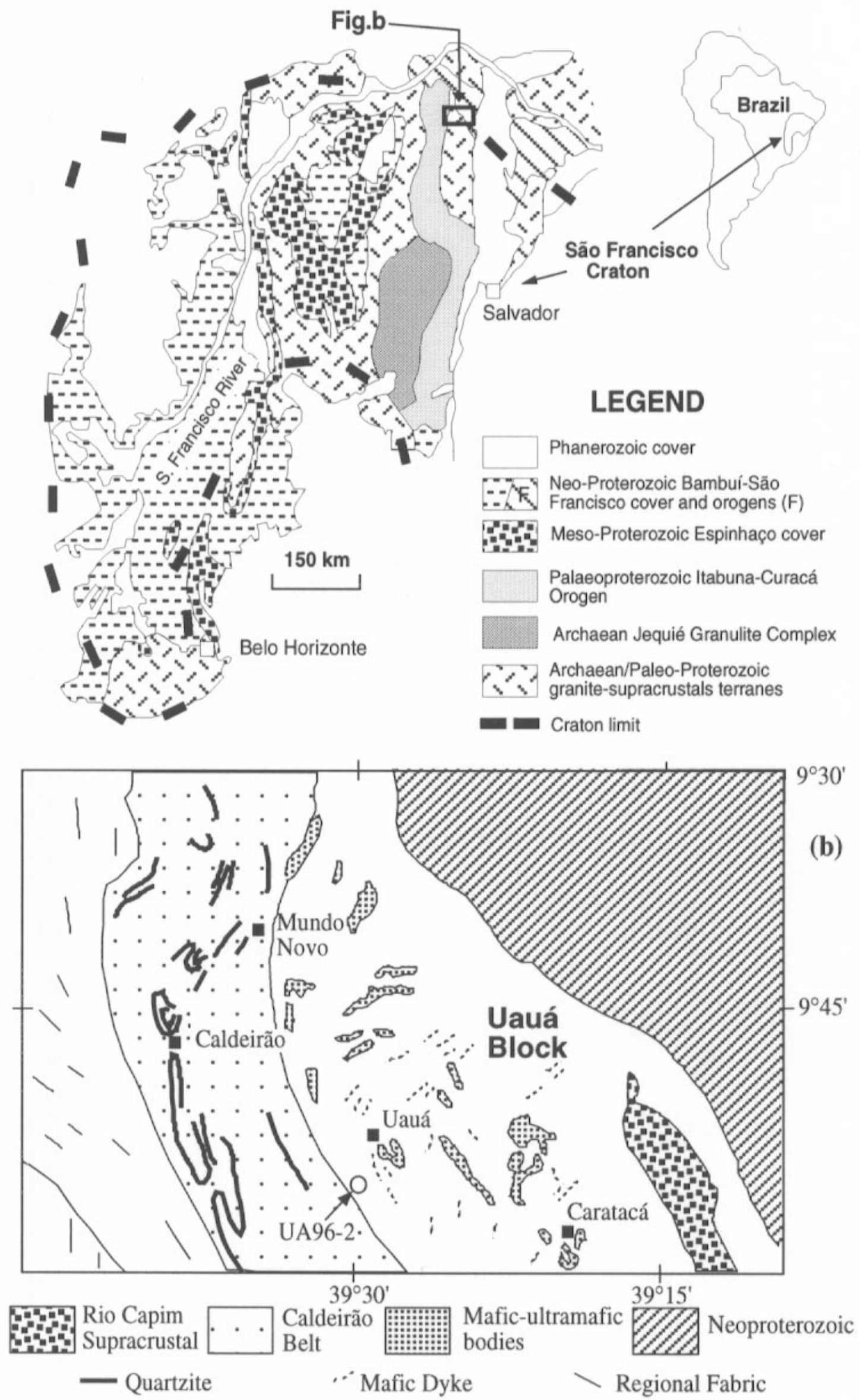

Figure 1-The São Francisco Craton (a) with location of the Uauá Block (b) and outcrop UA96-2. Modified after Inda and Barbosa (1978) and Jordan and Busch (1973). 


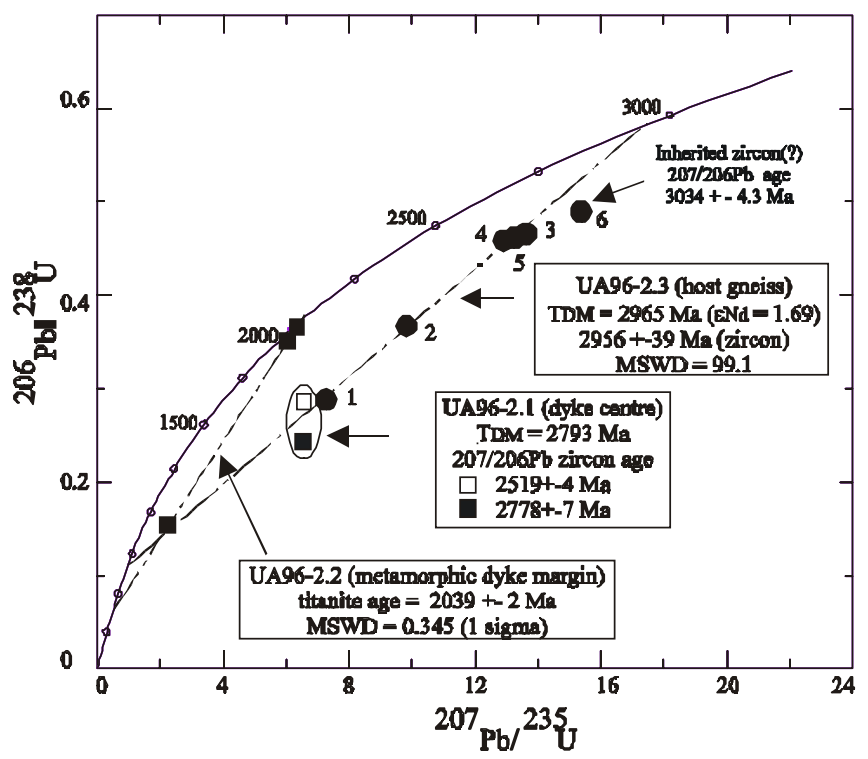

Figure 2-U-Pb ages of shear zone deformed mafic dyke (UA96-2.1, 2.2) and host gneiss (UA96-2.3), western boundary of the Uauá Block.

concordia intercepts, and weighted averages. Sm and $\mathrm{Nd}$ were dissolved in a HF-HNO mixture and extracted using AG-50W cation and $\mathrm{LN}$-spec resins ion exchange columns following the general procedures of Patchett and Ruiz (1987). Sm and Nd were loaded, respectively on Ta filament with $\mathrm{H}_{3} \mathrm{PO}_{4}$; and Re filament with $\mathrm{H}_{3} \mathrm{PO}$ and a thin coat of resin beads. Analyses are corrected for instrumental bias to a value for the La Jolla Nd standard of 0.511860 . Correction for blanks was insignificant for $\mathrm{Nd}$ isotopic compositions and for $\mathrm{Sm} / \mathrm{Nd}$ concentrations and ratios.

RESULTS AND DISCUSSION Analytical data are presented in Tables 1 and 2, whereas Fig. 2 shows a summary of our U-Pb geochronological and $\mathrm{Nd}$ isotope results.

Two discordia lines were obtained, one with three titanite magnetic fractions from the amphibolitic dyke margin $(2,039 \pm 2 \mathrm{Ma}$; sample
UA96-2.2) and another with four zircons of the host grey gneiss $(2,956$ $\pm 39 \mathrm{Ma}$; sample UA96-2.3).

The titanite age is of high quality, as revealed by one nearly concordant magnetic fraction and the good fit of the regression (MSWD $=0.345$ at 1 sigma). This age is here interpreted as the timing of metamorphism and deformation when titanite was formed. Direct dating of deformation using the U-Pb system in titanite was also achieved by Resor et al. (1996) on the Proterozoic Laramie Peak shear zone, Wyoming, USA

The age found on host gneiss deserves further comments. Two additional zircons from the gneiss (zircons 3 and 6 on Fig. 2) plot to the right of the discordia and were interpreted as inherited grains from older crust. Evidence of older crust in the Uauá Block come also from $\mathrm{U}-\mathrm{Pb}$ age dating of zircons from several rock units $(3,161-3,050 \mathrm{Ma}$, Oliveira et al. 1999, Cordani et al. 1999) and from Nd model ages (3,256-3,368 Ma cf. Oliveira et al. 1999). However, the observed whole-rock Nd model age of the gneiss, viz. 2,965 Ma sets a maximum age limit for it if the Sm-Nd system has not been disturbed.

Two zircons from the central portion of the mafic dyke (sample UA96-2.1) were also analyzed. Because only three zircon crystals could be picked up from the heavy mineral concentrate we have not been able to split them into magnetic fractions, nor get any discordia. However, their apparent ${ }^{207} \mathrm{~Pb} /{ }^{206} \mathrm{~Pb}$ ages are $2,519 \pm 4 \mathrm{Ma}$ and 2,778 $\pm 7 \mathrm{Ma}$, and the whole-rock Nd model age is $2,793 \mathrm{Ma}$, with great uncertainty, however, because of its high ${ }^{147} \mathrm{Sm} /{ }^{144} \mathrm{Nd}$ ratio $(0.18890)$. No firm conclusion can be drawn from these data, because the zircons have a high degree of discordance and may have come from the regional gneisses through contamination. Nevertheless, we suggest that the dyke age may be somewhere between 2,039 Ma, i.e. the age of dyke deformation, and its Nd model age of 2,793 Ma.

Finally, we would like to draw the following general conclusions from this study, with regional implications for understanding the geology of remnant Archaean nuclei in the São Francisco Craton and their subsequent reworking by younger tectonic events.

Most Archaean high-grade terrains have a complex geologic evolution, with a long history of volcanism, igneous intrusion, sedimentation, metamorphism and deformation. The reconstruction of their geology and tectonic settings are probably only possible with the help of good field relations and high-quality isotope data. From the studied gneisses and intrusive mafic dyke of the Uauá Block we can learn that Mesoarchean gneisses, possibly generated at an Andean-type

Table 1-Titanite (tit) and zircon ( $z r)$ U-Pb isotopic data from margin and center of mafic dyke and host gneiss.

\begin{tabular}{|c|c|c|c|c|c|c|c|c|c|}
\hline \multirow[b]{2}{*}{ Sample } & \multirow[b]{2}{*}{ Rock } & \multirow[b]{2}{*}{$\begin{array}{l}\text { Mineral } \\
\text { Fraction }\end{array}$} & \multirow[b]{2}{*}{$\begin{array}{l}\text { Weight } \\
\text { (mg) }\end{array}$} & \multicolumn{3}{|c|}{ Concentrations } & \multicolumn{3}{|c|}{ Corrected values } \\
\hline & & & & $\begin{array}{c}\mathrm{U} \\
\mathrm{ppm}\end{array}$ & $\begin{array}{c}\text { Total } \mathrm{Pb} \\
\mathrm{ppm}\end{array}$ & $\begin{array}{c}\text { Com Pb } \\
\text { ppm }\end{array}$ & ${ }^{206} \mathrm{~Pb} /{ }^{238} \mathrm{U}$ & ${ }^{207} \mathrm{~Pb} /{ }^{235} \mathrm{U}$ & ${ }^{207} \mathrm{~Pb} /{ }^{206} \mathrm{~Pb}$ \\
\hline UA96-2.3 & gneiss & 1-zr-m(1) & 0.003 & 767.75 & 270.57 & 31.4 & 0.289998 & 7.2759 & 0.181965 \\
\hline UA96-2.3 & gneiss & 2-zr-m(0) & 0.009 & 624.68 & 2697.1 & 6.33 & 0.368455 & 9.8091 & 0.193083 \\
\hline UA96-2.3 & gneiss & 3-zr-nm(-1) & 0.01 & 467.65 & 243.23 & 3.41 & 0.466012 & 13.6348 & 0.212202 \\
\hline UA96-2.3 & gneiss & 4-zr-nm(-1)ab & 0.003 & 342.8 & 173.73 & 3 & 0.458181 & 13.0217 & 0.206124 \\
\hline UA96-2.3 & gneiss & 5-zr-nm(-1)ab & 0.003 & 473.44 & 241.68 & 4.61 & 0.460827 & 13.2600 & 0.208692 \\
\hline UA96-2.3 & gneiss & 6-zr-nm(-1)ab & 0.002 & 207.42 & 137.94 & 20.9 & 0.49008 & 15.3702 & 0.227464 \\
\hline UA96-2.2 & dyke & tit-m(8)ab & 0.342 & 48.20 & 27.55 & 2.53 & 0.352048 & 6.0656 & 0.124961 \\
\hline UA96-2.2 & dyke & tit-m(6) & 0.351 & 28.74 & 17.52 & 1.21 & 0.365173 & 6.3211 & 0.125544 \\
\hline UA96-2.2 & dyke & tit-m(4) & 0.308 & 103.99 & 23.26 & 3.02 & 0.15267 & 2.2356 & 0.106205 \\
\hline UA96-2.1 & dyke & zr-nm(0.6)ab 1 & 0.002 & 392 & 124.45 & 6.4 & 0.285795 & 6.5464 & 0.166129 \\
\hline UA96-2.1 & dyke & $\mathrm{zr}-\mathrm{nm}(0.6) \mathrm{ab} 2$ & 0.002 & 595.6 & 169.78 & 10.6 & 0.244233 & 6,5404 & 0.194222 \\
\hline
\end{tabular}

Table 2-Sm-Nd isotopic data from mafic dyke's center and host gneiss

\begin{tabular}{|l|c|c|c|c|c|c|c|c|l|}
\hline & Rock & Age & $\mathrm{Sm}$ & $\mathrm{Nd}$ & ${ }^{147} \mathrm{Sm} /{ }^{144} \mathrm{Nd}$ & ${ }^{143} \mathrm{Nd} /{ }^{144} \mathrm{Nd}$ & $\mathrm{T}_{\mathrm{DM}}$ & $\varepsilon_{\mathrm{Nd}(0)}$ & $\varepsilon_{\mathrm{Nd}(\mathrm{t})}$ \\
\hline UA96-2.3 & gneiss & $2956(?)$ & 0.799 & 5.135 & 0.09405 & 0.510720 & 2965 & $-37,41$ & 1.69 \\
\hline UA96-2.1 & mafic dyke & $?$ & 1.881 & 6.019 & 0.18890 & 0.512600 & 2793 & $-0,75$ & \\
\hline
\end{tabular}


continental margin (zircon age $=2,956 \mathrm{Ma}, \mathrm{T}_{\mathrm{DM}}=2,965 \mathrm{Ma}$ and $\left.\varepsilon_{\mathrm{Nd}(\mathrm{t})=}=1.69\right)$, were deformed and later intruded by mafic dykes, which to some extent remained relatively undisturbed in low strain regions within the Uauá Block. During the Paleoproterozoic part of these dykes and their host gneisses have been deformed by the continentcontinent collisional event that originated the Itabuna-Salvador-Curaçá orogen, as evidenced by the $2039 \mathrm{Ma}$ age on syndeformational titanites from the amphibolite margin of a mafic dyke found within a highly deformed zone that separates the Uauá Block from the Caldeirão Belt. The main N-NW-trending deformation and associated high temperature amphibolite facies metamorphism observed in the latter is thus very likely to be of similar age, perhaps somewhat older owing to the possible lower closure temperature of the U-Pb system in titanites than in zircons; Indeed, detrital zircons from quartzites of the Caldei- rão Belt yield a metamorphic age of 2,076 \pm Ma (Mello et al. 1999). Despite the strong deformation and high-grade metamorphism during the Paleoproterozoic reworking event, zircons from the dyke's host gneiss allowed us to unravel part of the gneiss petrogenesis.

Similar studies are currently being carried out in other areas of the Salvador-Curaçá orogen, especially in mineral deposit districts, in order to understand their metallogenesis and provide geological models for exploration.

Acknowledgments: FAPESP and CNPq are greatly acknowledged for research grants to EPO. We thank W.R. van Schmus for laboratory facilities at Kansas University, USA, and A. Choudhuri for reviewing the manuscript. The comments of an anonymous reviewer greatly improved the paper.

\section{References}

Bastos Leal L.R., Teixeira W., Piccirillo E.M., Menezes Leal A.B., Girardi V.A.V. 1994 Geocronologia $\mathrm{Rb} / \mathrm{Sr}$ e K/Ar do enxame de diques máficos de Uauá, Bahia (Brasil) Geochimica Brasiliensis, 8:99-114.

Cordani U.G., Sato K., Nutman, A. 1999. Single zircon SHRIMP determinations from Archean tonalitic rocks near Uauá, Bahia, Brazil. In: South American Symposium on Isotope Geology, 2, Córdoba, Argentina, Actas, 27-30.

Inda H.A.V. \& Barbosa J.F. 1978. Mapa geológico do Estado da Bahia (Escala 1:1.000.000). Secretaria de Minas e Energia da Bahia.

Jordan H. 1972. Die Minas Gruppe in Nordost-Bahia, Brasilien. Geologisches Rundschau, 61:441-469.

Jordan, H. \& Busch, K. 1973. Mapa geológico da região de Uauá-Bedengó 1:100,000. Bundesanstalt für Bodenforschung (Hannover, Germany) \& SUDENE (Recife, Brazil).

Krogh T.E. 1973. A low-contamination method for hydrothermal decomposition of zircon and extraction of $\mathrm{U}$ and $\mathrm{Pb}$ for isotopic age determination. Geochimica et Cosmochimica Acta, 37:485-494.

Ludwig K.R. 1980. Calculation of uncertainties of U-Pb isotopic data. Earth and Planetary Science Letters, 46:212-220.

Ludwig K.R. 1990. Isoplot: a plotting and regression program for radiogenic isotope data, for IBM-PC compatible computers, Version 2.02. U.S. Geol. Surv. Open File Rep., 88-557, revision of Feb. 13, 44 pp. Plus program disk.

Mello E., Oliveira E.P., McNaughton N. 1999. SHRIMP U-Pb geochronology of detrital zircons from Early Precambrian quartzite of the Caldeirao Belt, NE São Francisco Craton, Bahia-Brazil. In: South American Symposium on Isotope Geology, 2, Córdoba, Argentina, Actas, 78-81.
Oliveira E.P., Lafon J-M., Souza Z.S. 1998. A Paleoproterozoic age for the Rio Capim volcano-plutonic sequence, Bahia, Brazil: whole-rock $\mathrm{Pb}-\mathrm{Pb}, \mathrm{Pb}$-evaporation and $\mathrm{U}$ $\mathrm{Pb}$ constraints. In: SBG, Congresso Brasileiro de Geologia, 15, Belo Horizonte, Anais, 14.

Oliveira E.P., Lafon J-M., Souza Z.S. 1999. Archaean-Proterozoic transition in the Uaua Block, NE São Francisco Craton, Brazil: U-Pb, Pb-Pb and Nd isotope constraints. In: SBG, International Symposium on Tectonics, 1, Lençois, Proceedings, Section 1, 38-40.

Patchett P.J. \& Ruiz J. 1987. Nd isotopic ages of crust formation and metamorphism in the Precambrian of eastern ands southern Mexico. Contribuition to Mineralogy and Petrology, 96:523-528.

Resor P.G., Chamberlain K.R., Frost C.D., Snoke A.W., Frost B.R. 1996. Direct dating of deformation: U-Pb age of syndeformational sphene growth in the Proterozoic deformation: $\mathrm{U}-\mathrm{Pb}$ age of syndeformational spher
Laramie Peak shear zone. Geology, 24:623-626.

Tilton G.R. 1973. Isotopic lead ages of chondritic meteorites. Earth and Planetary Science Letters, 19:321-329. 